\title{
Pedological memory in forest soil development
}

\author{
Jonathan D. Phillips ${ }^{\mathrm{a}, *}$, Daniel A. Marion ${ }^{\mathrm{b}}$ \\ ${ }^{a}$ Tobacco Road Research Team, Department of Geography, University of Kentucky, Lexington, KY 40506-0027, USA \\ ${ }^{\mathrm{b}}$ Forest Hydrology Laboratory, Southern Research Station, USDA Forest Service, 1000 Front Street, Oxford, MS 38655, USA
}

Received 8 May 2003; received in revised form 13 July 2003; accepted 5 August 2003

\begin{abstract}
Individual trees may have significant impacts on soil morphology. If these impacts are non-random such that some microsites are repeatedly preferentially affected by trees, complex local spatial variability of soils would result. A model of self-reinforcing pedologic influences of trees (SRPIT) is proposed to explain patterns of soil variability in the Ouachita Mountains, Arkansas. SRPIT postulates that trees are preferentially established on patches that are nutrient-rich and rock fragment poor relative to adjacent sites. The biomechanical effects of trees on soil, and decomposition of roots then maintain and reinforce the rock fragment and nutrient differences relative to surrounding soils, increasing the likelihood of successful future tree establishment. The links hypothesized in the SRPIT model are dynamically unstable, which would be necessary for the self-reinforcing mechanisms to operate. Soil variability in 16 study plots is dominated by local, within-plot variability, pointing to highly localized biological effects and consistent with the SRPIT model. Within each 0.127 ha plot, 4-11 different series, and 4-9 different rock fragment classes were found. Of the 10 paired pits at each plot, 3-7 pairs had different series in pits typically less than $1 \mathrm{~m}$ apart. On average, each of the 16 plots had 6.3 different soil types, 6 different rock fragment classes, and $60 \%$ of the sample pairs differing in soil series. Richness-area analysis of soil series, and of rock fragment classes, both indicate that pedodiversity is dominated by within-plot rather than between-plot variability. The vertical variations in the concentration of rock fragments in 40 of 58 soil pits is consistent with redistribution of soil material by tree throw, and there is also evidence of rock fragment displacement by tree growth and deposition in stump holes. Overall, results suggest that soil morphological effects of individual trees are an important source of soil spatial variability in forests, and that such effects are non-random over time. Thus even relatively homogeneous areas may be characterized by tree-rich patches which support repeated generations of trees, and tree-poor patches which more rarely host trees.
\end{abstract}

(C) 2003 Elsevier B.V. All rights reserved.

Keywords: Pedologic influences of trees; Forest soils; Soil variability; Soil morphology

\section{Introduction}

Individual trees may have significant impacts on the nature and properties of the soils they grow in. Beyond changes in fast-reacting and transient soil

\footnotetext{
* Corresponding author. Tel.: +1-859-257-6950; fax: +1-859-323-1969.

E-mail addresses: jdp@uky.edu (J.D. Phillips), dmarion@fs.fed.us (D.A. Marion).
}

chemical and microbiological processes, trees may have important influences on longer-lasting, persistent soil morphological properties. Soil scientists and geomorphologists have generally assumed that, in an area of reasonably consistent environmental constraints and edaphic controls, over time any given point in the forest ecosystem is equally likely to have a tree growing there. Further, it is typically assumed that over multiple generations of forest communities, the entire forest floor is eventually subject to the 
effects of trees. The purpose of this paper is to explore the possibility that ecological and pedological memory plays a key role in the relationships between tree locations and soil morphology. "Memory" in this sense occurs where the location of trees is influenced by past locations of trees, via the effects of trees on soil properties.

Few would argue that the assumption of random probability of seeding establishment and tree growth is strictly true at the microscale, recognizing the patchy nature of edaphic controls and resources. However, many soil scientists and geomorphologists are comfortable with this assumption as a generalization over pedological time scales, as long as one is considering sites that are consistent in terms of topography, drainage, aspect, microclimate, parent geology, and disturbance and management regimes.

This paper proposes an alternative conceptual model whereby self-reinforcing processes result in the same microsites preferentially being occupied by trees. Thus, rather than random probability of tree establishment and the entire soil cover eventually being influenced by tree effects, the proposed model suggests that there will be tree-rich areas where soils have repeatedly hosted trees, and tree-poor zones where trees have more rarely grown.

This framework is proposed and examined primarily in a pedogeomorphic context rather than an ecological context, owing to the nature of the field study that inspired it. In the course of research on relationships between soil morphology, vegetation, and forest management in the Ouachita National Forest, Arkansas, we noted unexpected spatial variation in soils over short distances and small areas, and within plots where the vegetation community, management, and history were uniform. The self-reinforcing pedologic influence of trees (SRPIT) conceptual model was devised as an effort to interpret or explain observed local variability.

The basic argument of the paper is based on the extreme variability in soil properties over small areas where (owing to the study design) parent material, topography and drainage, aspect, climate, and time are relatively constant. While biotic factors are readily invoked to explain many chemical and biological properties of soils, the observed variation in the Ouachita sites is based on variations in basic morphological properties such as soil thickness, rock fragment abundance and distribution, and presence of specific horizons. While these latter variations may be related to the effects of trees, the general pattern of soil variability is difficult to explain if all areas of the forest floor are eventually influenced, or affected with equal probability, by trees. The SRPIT model, drawing on published literature as well as our field observations, was devised to explain the observed soil landscape. The proposed model cannot be directly tested based on observations. Simulation modeling would also be ineffective, as any simulation model incorporating the basic postulates of the SRPIT model would inevitably produce results consistent with the model. Thus, the proposed model is evaluated based on three general criteria:

- Are the relationships between trees and soils in the model unstable? Instability would imply that minor variations should persist and grow, a necessity for creating the tree-rich and tree-poor zones postulated in the model.

- Is there pedological evidence supporting the mechanisms postulated in the model?

- Is the spatial pattern or signature of soil variability consistent with highly localized, self-reinforcing pedologic effects of trees?

\section{Background}

Vegetation influences soil via its effects on erosion and deposition, soil structure, organic matter dynamics, soil chemistry, hydrology, and bioturbation. Thus significant changes in the type of vegetation and vegetation cover typically have significant, and often major, effects on soils. These effects may occur in conjunction with disturbances such as fire or storms, human activities such as harvesting, or more gradual changes associated with processes such as succession. Causality is often uncertain in establishing relationships between soil properties and vegetation, as soil properties may determine, and/or be determined by, vegetation characteristics.

It is clear that at least short-term chemical and biological changes in soils accompany vegetation change. The literature suggests that it is at least possible that vegetation change over decadal time scales may result in significant long-term soil changes. 
Forest management practices in Bangladesh were directly linked to soil quality by Islam et al. (2001) over vegetation successional time scales. Graham et al. (1995) examined aggregate stability in California soils where native chapparal vegetation was restored by burning and replanting in 1946. After 41 years aggregate stability had increased about $15 \%$, and the volume of stable aggregates had increased sevenfold. In Denmark, Leth and Breuning-Madsen (1992) studied soil profile development and nutrient status in former heathland soils that were converted to agriculture in the 19th century and then afforested between 1914 and 1976. These biosequence studies showed that a mor layer may develop in 20-30 years, that the former Ap horizon will degrade over 40-80 years, and that base saturation will decrease rapidly after afforestation. Italian biosequences involving replacement of oak-dominated forests with Corsican pine and fir showed changes in soil morphology and pedogenetic processes over 50 years or less, as well as significant morphology differences between the pine and fir sites (Certini et al., 1998). In Michigan, spodic horizon development was stronger in regenerated forests than in nearby "stump prairies" (Barrett, 1997), where both areas were similar in their initial soils and were cut at the same time in the late 19th century. Schaetzl (1994) showed rapid changes in O horizon mass, thickness, and carbon content after fire for about 100 years following fire in Michigan hardwood forests.

There have been some relevant studies in southern US forests, but focussed mainly on nutrients and soil chemistry. Richter et al. (1994) documented soil chemical changes ( $\mathrm{pH}, \mathrm{Ca}, \mathrm{Mg}, \mathrm{K}$ ) over three decades in an old-field loblolly pine ecosystem in South Carolina. At the same site, Harrison et al. (1995) showed rapid soil carbon changes associated with land use and management changes, with a 12 -year $\mathrm{C}$ turnover time. At an upper Piedmont site in South Carolina, Van Lear et al. (2000) showed that decomposing loblolly pine taproots provided nutrient-rich microsites for establishment of new trees, thus suggesting the possibility of long-term persistence of local pedologic impacts. At 135 Kentucky sites, Boettcher and Kalisz (1990) showed variations in soil $\mathrm{pH}, \mathrm{Ca}, \mathrm{Mg}, \mathrm{N}$ and litter mass associated with individual tree species.

The Ouachita Mountains study area is focussed on sites which are believed to have once hosted, or which could be managed to host, shortleaf pine-bluestem savanna communities. Infiltration and interrill erosion in pine-bluestem sites in Louisiana and their relationship to prescribed burning over 10- to 20-year periods were examined by Dobrowolski et al. (1992), who found that the soils and ecosystems were resilient to changes associated with burning. This suggests limited memory at the ecosystem level. Studies of timber harvest and periodic burning in the Ouachita Mountains by Masters et al. (1993) showed no increase in soil $\mathrm{pH}$, and effects of burning on most soil chemical properties generally persisted less than 2 years. Timber harvest, periodic prescribed fire, and subsequent plant succession redirected nutrient cycling pathways and enhanced soil nutrient levels. Other work in the Ouachita Mountains has shown clear evidence of short-term soil changes in response to harvesting, but the studies do not indicate the long-term pedologic impacts (Stanturf et al., 2000).

\subsection{Effects of individual trees}

Individual trees may have significant effects on soil morphology by several mechanisms, including a focus of organic-acid-enriched moisture flux, and by primary and secondary effects of tree throw (Boettcher and Kalisz, 1990; Crampton, 1982; Certini et al., 1998; Schaetzl, 1990; Schaetzl et al., 1989, 1990; Vasenev and Targul'yan, 1995; Wilson et al., 1997; Zinke, 1962). It has also been shown that at least in some cases these effects persist long after the tree is gone, thus leaving a "signature" that provides information about tree spacing, forest characteristics, and other ecological variables (Mossa and Schumacher, 1993; Retallack, 1990; Schaetzl, 1990; Schaetzl and Follmer, 1990; Small et al., 1990; Stephens, 1956; Vasenev and Targul'yan, 1995; Wilson et al., 1997).

Tree throw or wind throw (see Schaetzl et al., 1989 for a review) occurs when wind or some other factor topples a tree, uprooting the base of the tree and a mass of soil. In the Ouachitas ice storms rather than wind seem to be the primary agent of tree throw. In addition to the immediate soil disturbance and redistribution, the depression created by the uprooting, erosion of the uprooted soil mass and decomposition or combustion of the downed tree create a characteristic mound-pit topography. Studies from a number of forested environments suggest that tree throw is quite common (Schaetzl et al., 1989; Vasenev and Targul'yan, 1995). 
A review of 21 studies, mostly from North America but also including sites in Europe, Asia, and New Zealand (Schaetzl et al., 1989) showed that tree throw mound-pit systems, while covering only a small portion of the forest surface in some areas, typically occupied $10-50 \%$ of the forest soil surface. This review also suggested that nearly complete canopy destruction by large scale events such as hurricanes occurs with a mean frequency ranging from 100 to 25,000 years, but with a typical frequency in North American forests on the order of 1000-2000 years. In Russia a periodicity of mass tree throw of 630-1000 years was found, while tree throw involving individual trees or small groups at a given forest location has an estimated periodicity of 150-560 years (Vasenev and Targul'yan, 1995). Brewer and Merritt (1978) found that a pedon in Michigan would be uprooted at least once every 3571-5000 years, and that the entire forest floor is ultimately subjected to tree throw. In Puerto Rico, Scatena and Lugo (1995) showed that 9.4-24.5\% (varying by geomorphic setting) of a forest surface in Puerto Rico is occupied by tree uprooting features and another $1.4-14 \%$ by broken-off tree boles.

Tree throws influence soil morphology directly, and also via indirect influences of the resultant microtopography. Uprooting and creation of mound-pit pairs leads to redistribution of sediment, organic matter, and water. This in turn affects weathering, soil chemistry, and translocation (Vasenev and Targul'yan, 1995; Schaetzl et al., 1990; Schaetzl, 1990). Uprooting and subsequent slumping also mixes soil horizons (Stephens, 1956; Schaetzl et al., 1990; Schaetzl, 1990). Organic matter from the decomposing tree, as well as the indirect effects via forest and soil organic matter turnover, also influence soil organic properties, chemistry, and weathering (Scatena and Lugo, 1995; Schaetzl et al., 1990; Vasenev and Targul'yan, 1995). Accumulation of snow and the formation of impermeable ice layers varies between the mounds and pits; accordingly microclimatic effects on pedogenesis are also important (Vasenev and Targul'yan, 1995; Schaetzl, 1990; Schaetzl and Follmer, 1990).

Coarse clasts may also be brought to the surface by tree throw, which not only modifies the soil profile but has subsequent effects via surface armoring (Small et al., 1990; Schaetzl and Follmer, 1990). The persistence of tree throw gravel lags in a number of soils was noted by Johnson (1990).
Schaetzl and Follmer (1990) found that tree throw mounds persist for more than 1000 years in Michigan and Wisconsin. The longevity is partly due to feedback effects on soils which inhibit erosion. These include gravel armoring as described above, the interception of runoff by upslope pits, and the greater frequency and duration of freezing and impermeable frozen layers on mounds. On an Ultisol landscape in North Carolina, Phillips et al. (1994) found large and irregular variations in thickness of surficial soil horizons. The variability was attributed to the persisting effects of trees, via tree throw and stemflow. The soil stratigraphy of a mound-pit system showed that subsequent smoothing of the microtopography alone, without any subsequent pedogenetic effects, would result in a $20-60 \mathrm{~cm}$ difference in $\mathrm{A}$ and $\mathrm{E}$ horizon thickness over a horizontal distance of less than $2 \mathrm{~m}$.

In some soils (particularly podzols), there are obvious instances of individual tree effects on soils in the form of "basket podzols". These occur where stemflow concentration and organic acids result in leaching of clay, iron, and other materials immediately beneath trees. This leads to thickened E and deeper B horizons, and a basket-like effect in soil horizonation. Persistence of podzol baskets after the tree and its stump are gone is indicated by the presence of baskets in paleosols and their use as evidence of tree spacing in ancient forests (Retallack, 1990, p. 189). This phenomenon was invoked to explain otherwise unexplained spatial variability of B horizon depths in Spodosols in coastal North Carolina (Phillips et al., 1996).

Mossa and Schumacher (1993) describe strong evidence for the persistence of pedologic effects of tree roots. Tapered cylindrical pedologic features in south Louisiana soils were shown to be fossil tree casts. As trees die they leave a subsurface void as the major tap roots decompose, and result in localized changes in soil chemistry, bulk density, and porosity. These in turn create the tree cast features. Mossa and Schumacher measured 187 cylinders exposed in five road cuts, suggesting that the features are widespread, at least in south Louisiana. Mossa and Schumacher (1993) cite other studies where similar features have been examined. Phillips (1999) notes the presence of numerous apparent fossil tree casts in some Pleistocene paleosols in eastern North Carolina.

Of particular interest in this study is the potential for trees to alter distributions of rock fragments 
independently of tree throw, but the literature on this is sparse, even though Lutz and Griswold (1939) pointed out this phenomenon. It seems obvious that root growth is incapable of moving large rock fragments, since tree throws and other exposures show numerous examples of directional changes in root growth when a stone is encountered. However, the upward and outward displacement of soil en masse is capable of moving rocks. An obvious illustration is seen in urban settings where sidewalks are bowed upward and out by tree and root growth.

\section{Conceptual model}

When a tree becomes established there are three implications with respect to rock fragments. First, the presence of the tree prevents the import of rock fragments by processes such as mass wasting and faunalturbation to that specific spot. Second, displacement of soil by tree growth may move fragments in the soil away from the tree. Third, there is the possibility of tree throw and the subsequent redistribution of coarse clasts. All three phenomena either impoverish the growth site of rock fragments or inhibit input of new fragments. We assume that seed germination and tree growth are both inhibited by high rock fragment concentrations. Thus tree effects on rock fragments may have the effect of creating a more favorable microsite for future tree establishment.

Decomposition of dead trees creates local soil organic matter concentrations and releases nutrients. The creation of localized nutrient-rich microsites associated with individual trees or tree/shrub patches has been most intensively studied in semiarid and savanna environments, but the phenomenon operates in moist forests as well (Boettcher and Kalisz, 1990; Van Lear et al., 2000). Of particular relevance is Van Lear et al.'s (2000) work in South Carolina showing that decomposing pine taproots provide nutrient-rich microsites

(A)

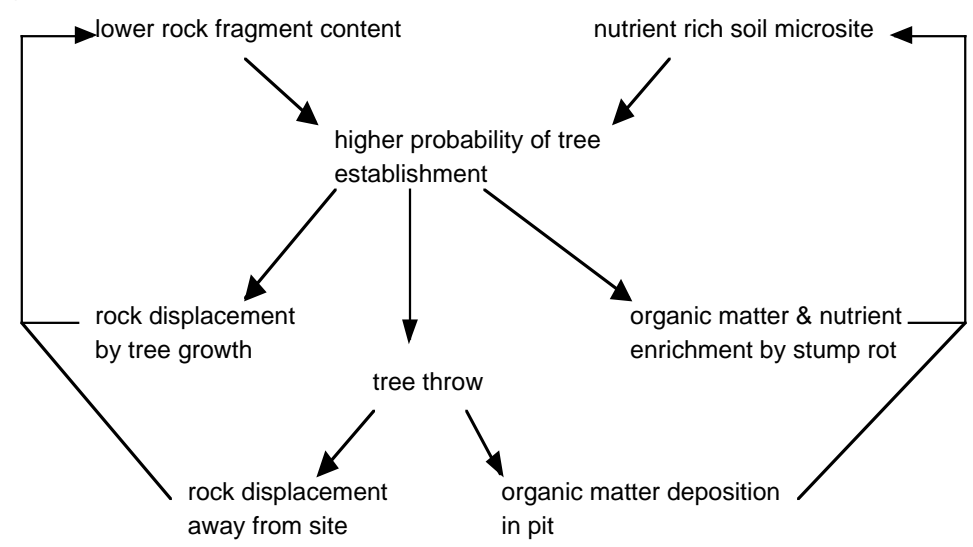

(B)

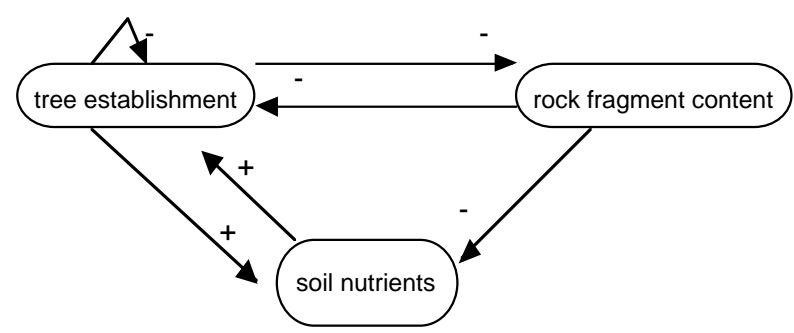

Fig. 1. The SRPIT (self-reinforcing pedologic influences of trees) conceptual model: (A) the major hypothesized causal pathways; (B) the positive and negative interactions between the major system components. 
for establishment of new trees. This provides another self-reinforcing pathway whereby the existence of a tree may increase the likelihood that a future tree will occupy the same location. Organic matter accumulation in tree throw pits might have the same effect.

The self-reinforcing mechanisms are shown in Fig. 1, the core of the SRPIT model. Fig. 1B shows the interactions between tree establishment, soil rock fragment content, and soil nutrients in terms of positive and negative relationships. The stability of the model in Fig. 1B can be examined using qualitative stability analysis. Beyond the links that are obvious from Fig. 1A, a self-limiting link is shown for trees, based on resource competition and density dependence (i.e., establishment of a seedling will inhibit establishment of immediately adjacent seedlings, and once a tree occupies the site, no other tree can occupy it). It is further assumed that rock fragment content is inversely related to nutrient status.

It is also possible that self-reinforcing tree/soil interactions occur via tree effects on soil thickness (depth to bedrock or impermeable layer) as shown in Fig. 2. Tree growth rates and productivity tend to be greater on deeper soils, as evidenced by the prominent role of depth in determining the site index. Larger trees would be expected not only to have deeper root penetration, but also to have greater stemflow effects on leaching, translocation, and other soil thickness processes. Once a tree is gone, the thicker soil would provide a competitive advantage for seedlings, increasing the probability of tree establishment. This mechanism is not considered in this study or incorporated in the SRPIT model because the parent material of the study area soils contains numerous joints, fractures, and bedding planes tilted to near-vertical. Further, many of the shales are soft enough, particularly when weathered, to permit root penetration.

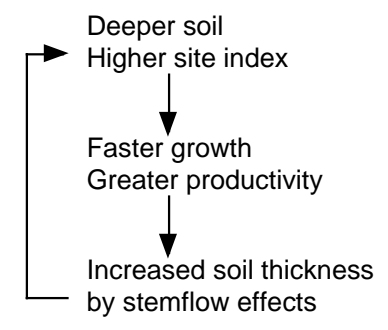

Fig. 2. Possible self-reinforcing relationships between soil depth and tree establishment.
Thus it is not felt that soil depth is a critical localscale influence on tree establishment.

\section{Study area and methods}

\subsection{Study area}

The Ouachita Mountains cover an area approximately $100 \mathrm{~km}$ wide north-south and $320 \mathrm{~km}$ eastwest in central Arkansas and eastern Oklahoma (Fig. 3). They consist of a complex of east-west trending ridges and intermontane basins. Ridges are narrow and parallel with moderately steep slopes and sharp, even crests. Ridges range from 230 to $850 \mathrm{~m}$ above sea level, while intermontane valleys range from 150 to $380 \mathrm{~m}$. Local relief varies from 75 to $530 \mathrm{~m}$, increasing from east to west.

The Ouachita Mountains are predominantly composed of extensively folded and faulted, Paleozoic sedimentary rocks. Sediments were deposited from the Early Ordovician to Middle Pennsylvanian, and originated from a wide variety of marine sources (Stone and Bush, 1984). Lithification produced alternating layers of sandstone and shale (Jordan et al., 1991) along with lesser amounts of quartzite, novaculite, and chert. From the Middle Pennsylvanian through the Permian, the area was uplifted above sea level and extensively deformed through sequential periods of folding, decollement, and faulting (Stone and Bush, 1984). Subaerial erosion has occurred almost continuously since the Middle Pennsylvanian.

The 16 sample sites used in this study fall within three lithologic units: the Stanley Shale, Jackfork Sandstone, and Atoka Formation. These units cover an extensive portion of the Quachita Mountains and are similar in that they all consist of steeply dipping, extensively faulted, intermixed beds of fine- to medium-grained sandstones and fine-grained shales. They differ in the relative proportions of each rock type and their age. The Stanley Shale contains the most shale and is Mississippian in age. The Jackfork contains the most sandstone and is of Early Morrowan age. The Atoka Formation is Atokan in age and consists of roughly equal proportions of sandstone and shale. Where exposed, the shales are deeply weathered and highly erodible, whereas the sandstones are noticeably less altered and more durable. 


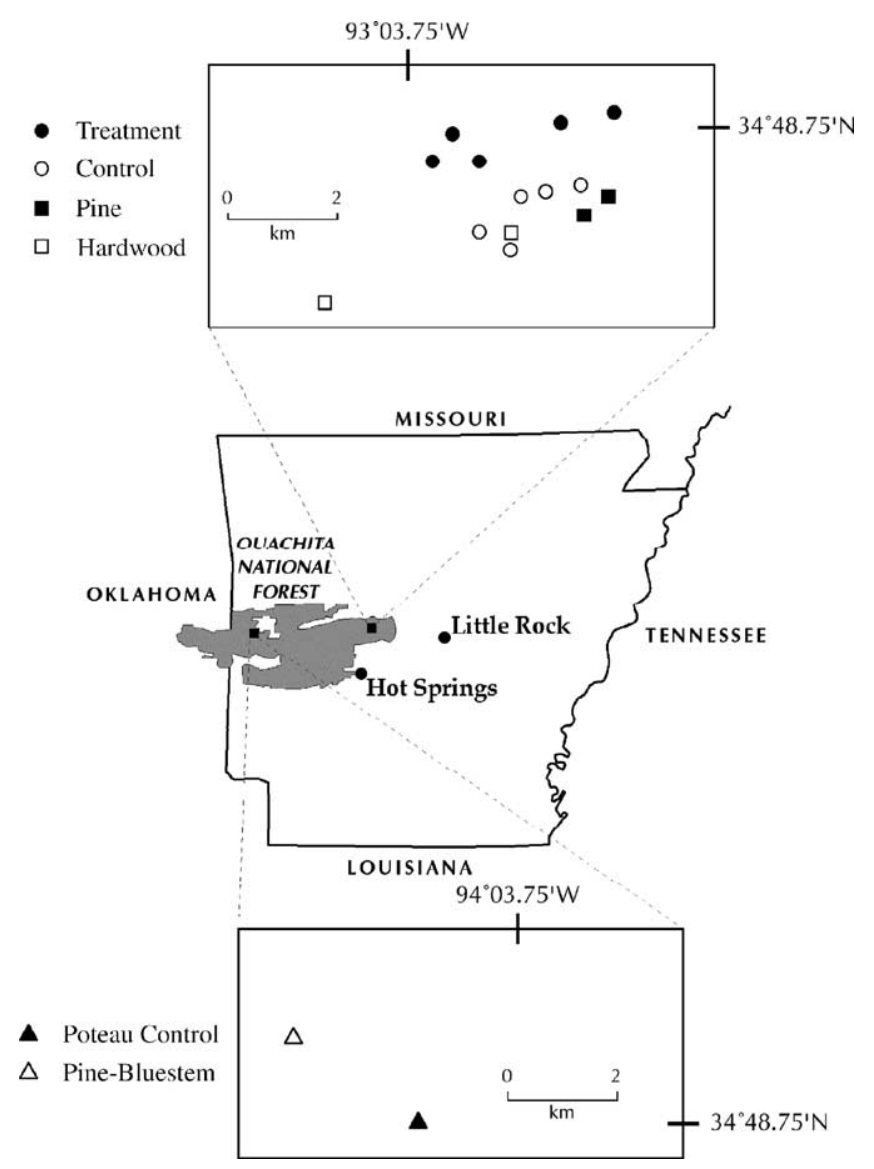

Fig. 3. Study area.

The contemporary climate for the Ouachita Mountains is humid subtropical. Average daily summer temperatures range from 20 to $30^{\circ} \mathrm{C}$, while winter temperatures range from 4 to $10{ }^{\circ} \mathrm{C}$. Average annual precipitation is $130-140 \mathrm{~cm}$, occurring primarily as rain during warm-period thunderstorms or cool-period frontal events. Precipitation is distributed roughly equally throughout the year, but with the maximum monthly precipitation occurring during the spring. Humidity is high from the late spring to early fall, but decreases substantially outside this period.

The soils covering the hillslopes and ridges are primarily medium-textured, well-drained, stony Hapludults. These soils have a thermic temperature regime, an udic moisture regime, and siliceous or mixed mineralogy. On steeper slopes or higher elevations, soil depths are shallow to moderate, whereas on more gentle slopes and benches, soils are moderately deep to deep (Haley, 1979; Laurent et al., 1989; Townsend and Williams, 1982).

The current forest vegetation consists of oak-hickory (i.e., hardwood-dominated), shortleaf pine (pinedominated), and oak-pine (mixed pine-hardwood) forest types (USDA Forest Service, 1999). The present composition of the forest vegetation has only existed during the last 4000 years (Delcourt and Delcourt, 1991). Prior to the start of Euro-American settlement approximately 200 years ago, it is believed that forest stands were generally more open than today and had somewhat different composition and structure (Foti and Glenn, 1991). The dramatic decrease in fire frequency during this period may explain these changes (Foti and Glenn, 1991). 


\subsection{Sample design}

The sample design was hierarchical, and partly dictated by a broader study of the silvicultural, ecological, and pedological effects of forest management and ecosystem restoration practices. Two areas were delineated, representing treatment and untreated control areas where the US Forest Service is seeking to restore the shortleaf pine-bluestem community. This entails the thinning of hardwoods and controlled burning in mixed pine-hardwood stands. Within the treatment and control areas, five plots were established for soil studies. The plots are circular, with a $66 \mathrm{ft}(20 \mathrm{~m})$ radius from center points along previously established vegetation transects. All plots are on generally southern aspects, and on sideslopes (e.g., both ridgetops and valley bottoms were avoided). Six additional plots were established to represent other vegetation communities in similar topographic settings in the study region. Two were in pine-dominated forests that are closedcanopy pine forests, as opposed to the savanna-like pine-bluestem communities. Two were in hardwooddominated stands. All the pine- and hardwood-dominated stands were on generally north-facing slopes, as they do not occur on southern exposures in the area. One plot was established within an area where an ecosystem believed to be the Ouachita National Forest's closest approximation to a pre-European pine-bluestem community has been produced by more than two decades of controlled burning. A final plot was established in south-facing, pinedominated stand identified by the Forest Service as being undisturbed-never cleared, burned, or actively managed.

In each plot 10 pairs of soil pits were established by flagging the 10 largest pieces of coarse woody debris (only debris that appeared to be natural, as opposed to logging slash, was flagged). At each of these sites a companion flag was set. These were generally within $1 \mathrm{~m}$ of the original site, but occasionally farther away to avoid surface rock outcrops or trees. No pair was more than $3.25 \mathrm{~m}$ apart. Soils were sampled at these flagged points, representing 20 samples at each plot. The woody-debris based site selection was designed to facilitate other, related studies of soil carbon, and in this study the sample pits are treated simply as paired samples.
Pits generally consisted of approximately circular pits about $30 \mathrm{~cm}$ in diameter. Most pits extended to bedrock or a lithic or paralithic contact; in some cases additional augering was necessary to sample the entire soil thickness. The depth and sequence of horizons was recorded, along with the texture and Munsell color of the A and upper B horizons, rock fragment content of the B horizon, and depth to bedrock or a lithic or paralithic contact. Pedogenic features which were systematically recorded when encountered included stone lines and stone zones, redox features, and buried organic matter. The general lithology of rock fragments was also recorded by breaking at least five fragments per pit with a geological hammer. Three full-size soil pits were excavated at each plot (with three exceptions; one plot had two pits and two plots had four pits) and described (19 by the authors; 39 by Ken Luckow, Soil Scientist, Ouachita National Forest). The descriptions are not discussed in detail in this paper. Standard US Department of Agriculture methods and procedures were followed (Soil Survey Division Staff, 1993).

Tree throws were inventoried at each plot, and the dimensions of the rootwad measured. Stumps and standing dead trees were also inventoried, and the diameter at breast height (or at the top of the intact bole) was measured to estimate basal area. Only stumps and trees with a diameter of $5 \mathrm{~cm}$ or greater were included.

\subsection{Soil series}

The soils were classified according to the US soil taxonomic system. This was accomplished by constructing an ad hoc soil key designed to distinguish among those soil series mapped and recognized to exist on side slopes and other uplands of the Ouachita Mountains in sandstone, shale, and/or quartz geology. Series mapped in these settings were identified based on published soil surveys of Perry, Saline, and Sebastian Counties, Arkansas, the Official Series Descriptions database, and previous soil studies by the US Forest Service (Haley, 1979; Laurent et al., 1989; Soil Survey Division, 2001; Townsend and Williams, 1982; Ken Luckow, personal communication, 2001). A key to distinguish among this population on the basis of features observed in the soil pits was constructed. The soils are distinguished from each other in 
this context primarily on the basis of solum thickness (classes of less than 50, 50-100, 100-150, and $>150 \mathrm{~cm}$ ), dominant parent material (shale or sandstone), rock fragment content in the B horizon, soil texture, colluvial deposition as indicated by a $2 \mathrm{Bt}$ horizon, and presence or absence of a Bt horizon. Other discriminators in the key which turned out to play a minor role in distinguishing the observed soils included drainage class or the presence of redox features. In addition to the recognized series five additional soils were found and identified either as variants of existing series (soils otherwise identical to the Clebit and Bismarck series, but with a Bt horizon; and soils otherwise similar to the Tuskahoma series, but coarser) or at higher taxonomic levels (Udorthents).

\subsection{Rock fragment classes}

The nature and distribution of rock fragments is critical in interpreting the development of soils and regoliths in the study area. The sample pits were grouped into 1 of 12 classes based on the presence or absence of surface and/or subsurface stone lines or stone zones, and three classes of volumetric rock fragment abundance in the B horizon $(<35,35-70$, and $>70 \%$ ). The $35 \%$ threshold separates skeletal from non-skeletal families; $70 \%$ was an arbitrary threshold established during fieldwork separating horizons that gave the impression of "dirty rocks" as opposed to "rocky dirt". The 12 classes (Table 1) represent various combinations of presence/absence of surface

Table 1

Explanation of rock fragment classes used in the study

\begin{tabular}{rlll}
\hline Class & $\begin{array}{l}\text { Surface stone } \\
\text { zone/line }\end{array}$ & $\begin{array}{l}\text { Subsurface } \\
\text { stone zone/line }\end{array}$ & $\begin{array}{l}\text { B horizon rock } \\
\text { volume }(\%)\end{array}$ \\
\hline 1 & No & No & $<35$ \\
2 & Yes & No & $<35$ \\
3 & Yes & Yes & $<35$ \\
4 & Yes & No & $35-70$ \\
5 & Yes & Yes & $35-70$ \\
6 & No & No & $35-70$ \\
7 & No & No & $>70$ \\
8 & Yes & No & $>70$ \\
9 & No & Yes & $>70$ \\
10 & Yes & Yes & $>70$ \\
11 & No & Yes & $<35$ \\
12 & No & Yes & $35-70$ \\
\hline
\end{tabular}

and/or subsurface stone lines or zones and the three classes of B horizon stone abundance.

Fragment content was estimated by strike tests, based on the percentage of time a knife point or metal rod thrust $1 \mathrm{~cm}$ into the soil face struck a rock fragment. In the small sample pits only the B horizon fragment content was routinely assessed (due to the role of this parameter in soil taxonomy). Due to the difficulty of measuring in $30 \mathrm{~cm}$ diameter pits, in many cases horizons with relatively few or with a great many stones were classified as less than 35 or greater than $70 \%$ rock fragments, respectively. In the full soil pits rock content was assessed for every horizon.

\subsection{Stability analysis}

The stability of the system in Fig. 1B was determined with qualitative asymptotic stability analysis using the Routh-Hurwitz criterion. The method is described in a number of mathematical texts (e.g., Puccia and Levins, 1985; Fishwick and Luker, 1991) and is applied to geomorphological, pedological and ecological problems by a number of workers (e.g. Logofet, 1993; Phillips, 1993, 1999). The model was translated into an interaction matrix, where the components are as in Fig. 1B where $a_{i j}$ indicates the positive, negative, or zero influence of the $i$ th component to the $j$ th component. The Routh-Hurwitz criterion holds that the system is stable if and only if all coefficients of the characteristic equation of the matrix are negative, and if the Hurwitz determinant is negative.

\subsection{Soil spatial variability}

The relative importance of local, within-plot sources of soil variation as opposed to broader-scale, between-plot variations was assessed using diversityarea relationships. Within each of the 16 sample plots a regression equation of the form:

$\log S_{i}=c_{i}+b_{i} \log N_{i}$

was developed, where $S_{i}$ is the number of soil types (or soil rock fragment classes) in the $i$ th plot as a function of the number of samples $N_{i}$ (a surrogate for area). A similar equation was developed for the study area as a whole; e.g. $\log S=c+b \log N$ (Fig. 4). 


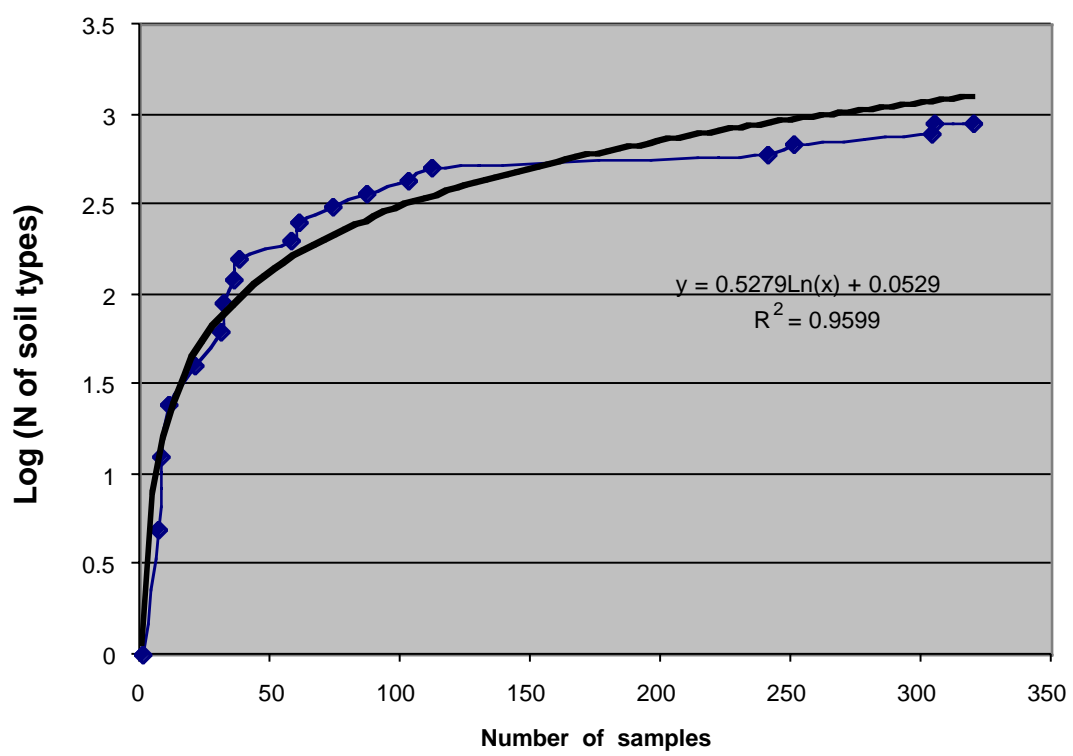

Fig. 4. Relationship between the number of sample sites and soil diversity for the entire study area.

The ratios $\bar{b}_{i} / b$ and $\bar{c}_{i} / c$ provide an indication of the relative importance of local, within-plot vs. betweenplot variability in soil richness. Because of the sampling scheme the intercept $c$ should be very close to unity (one sample must yield one soil), so this parameter, representing the intrinsic diversity independent of area, is of little interest. The exponent $b$ represents the rate at which soil diversity increases with area (the rate at which new soils are encountered as the number of sample pits is increased). If $\bar{b}_{i} / b>1$ it would indicate a prevalence of local, within-plot sources of soil diversity, a result consistent with the SRPIT model.

The use of richness-area relations as described above, and the validity of the power function relationship $\left(S=c N^{b}\right)$ for soils is described in detail elsewhere (Ibañez et al., 1995, 1998; Ibañez and De Alba, 2000; Phillips, 2001).

\section{Results}

\subsection{Stability analysis}

The SRPIT model as depicted in Fig. 1 can be translated into the interaction matrix shown in Table 2.
The matrix has the following characteristic equation:

$$
\begin{aligned}
& \lambda^{3}-a_{11} \lambda^{2}+\left[\left(-a_{12}\right)\left(-a_{21}\right)+a_{13} a_{31}\right] \lambda \\
& \quad+\left(-a_{12}\right)\left(-a_{23}\right)\left(a_{31}\right)=0
\end{aligned}
$$

The $\lambda$ are the complex eigenvalues of the matrix, the real parts of which are the system's Lyapunov exponents. The second coefficient is positive, violating the stability criterion, indicating that the system is unstable.

Instability implies that minor variations in initial conditions, or the effects of small perturbations, would tend to persist and grow over time. This is necessary for the SRPIT model, as it implies an increasing divergence over time between rock-rich, nutrient-poor microsites less likely to support trees, and rock-poor, nutrient-rich microsites where trees are more likely to establish.

Table 2

Interaction matrix for Fig. 1

\begin{tabular}{llll}
\hline & Tree & Rocks & Nutrients \\
\hline Tree establishment & $-a_{11}$ & $-a_{12}$ & $a_{13}$ \\
Soil rock fragments & $-a_{21}$ & 0 & $-a_{23}$ \\
Soil nutrients & $a_{31}$ & 0 & 0 \\
\hline
\end{tabular}




\subsection{Soil variability}

The sampling plots are small (less than $0.13 \mathrm{ha}$ ). There are local variations in slope gradient, aspect, and drainage due to microtopographic irregularities, but variation in soil-forming factors is small in general, and minimized during site selection.

Table 3 shows the soils found at the study sites, and Table 4 summarizes the taxonomic variability of the study plots. Within each 0.127 ha plot, $4-11$ different series, and 4-9 different rock fragment classes were found. Of the 10 paired pits at each plot, 3-7 pairs had different series in pits typically less than $1 \mathrm{~m}$ apart. On average, each of the 16 plots had 6.3 different soil types, 6 different rock fragment classes, and $60 \%$ of the sample pairs differing in soil series. Given that the plots are considerably smaller than a typical soil mapping unit delineation, and chosen to minimize environmental

Table 3

Taxonomy of soils mapped at the study sites

\begin{tabular}{ll}
\hline Series name or soil type & Taxonomy $^{\text {a }}$ \\
\hline Bengal & Typic Hapludults \\
Bismarck & Typic Dystrudepts \\
Bismarck-Bt & bithic Hapludults \\
Carnasaw & Typic Hapludults \\
Clebit & Lithic Dystrudepts \\
Clebit-Bt $^{\mathrm{c}}$ & Lithic Hapludults \\
Enders & Typic Hapludults \\
Endsaw & Oxyaquic Hapludalfs \\
Honobia & Typic Hapludults \\
Littlefir & Oxyaquic Hapludults \\
Nashoba & Typic Dystrudepts \\
Pirum & Typic Hapludults \\
Sherless & Typic Hapludults \\
Sherwood & Typic Hapludults \\
Stapp & Aquic Hapludults \\
Townley & Typic Hapludults \\
Tuskahoma & Albaquic Hapludalfs \\
Tuskahoma taxadjunct & ${ }^{\mathrm{d}}$ \\
Udorthents & Lithic Dystrudepts \\
\hline
\end{tabular}

\footnotetext{
${ }^{a}$ Taxonomy refers to the suborder level of US soil taxonomy.

${ }^{\mathrm{b}}$ Similar to the Bismarck series but with a Bt horizon, or similar to the Honobia series, but with a solum thickness less than $50 \mathrm{~cm}$.

${ }^{\mathrm{c}}$ Similar to the Clebit series but with a Bt horizon, or similar to the Pirum series, but with a solum thickness less than $50 \mathrm{~cm}$.

${ }^{\mathrm{d}}$ Similar to the Tuskahoma series, but lacking low chromas and/or clay texture in the B horizon.

${ }^{\mathrm{e}}$ Soils with A-C profiles lacking B horizons. One pedon was thapto-histic, indicating an organic, histic layer buried by mineral soil.
}

Table 4

Within-plot soil variability, showing the number of different series or soil types, the number (out of 10 pairs in each of plot) of sample pairs where the series differed within the pair, and the number of different rock fragment classes within each plot

\begin{tabular}{lcll}
\hline Plot & $\begin{array}{l}\text { No. of } \\
\text { series }\end{array}$ & $\begin{array}{l}\text { Differing } \\
\text { pairs }\end{array}$ & $\begin{array}{l}\text { Rock fragment } \\
\text { classes }\end{array}$ \\
\hline 3200 p4 & 4 & 5 & 4 \\
3826 p28 & 6 & 5 & 5 \\
4025 p40 & 7 & 3 & 6 \\
3100 p1 & 6 & 7 & 5 \\
3000 p2 & 8 & 8 & 9 \\
3428 p34 & 6 & 5 & 5 \\
3514 p12 & 5 & 6 & 6 \\
3514 p8 & 7 & 8 & 5 \\
3912 p10 & 5 & 4 & 4 \\
3627 p34 & 8 & 7 & 6 \\
HW1 & 6 & 6 & 9 \\
HW2 & 6 & 5 & 5 \\
AC1 & 7 & 7 & 5 \\
Flattop & 6 & 7 & 7 \\
Pine-bluestem & 4 & 4 & 9 \\
Poteau control & 10 & 9 & 8 \\
Mean & 6.3 & 6.0 & 6.1 \\
Coefficient of variation & 4.1 & 3.6 & 3.5 \\
\hline
\end{tabular}

variability, Table 2 suffices to demonstrate a high degree of variability over short distances and small areas.

The richness-area relationship for soil types is $S=1.05 N^{0.53}$ for the study area as a whole. For the individual plots, the mean values are $S_{i}=1.1 N^{0.61}$. As expected, $c$ values are near unity, ranging from 0.88 to 1.36 for individual plots. The exponent values range from 0.40 to 0.76 . This is higher than the values found for a similarly detailed study in an agricultural area of the southeastern coastal plain, where $b$ values ranged from 0.39 to 0.72 , with a mean of 0.53 (Phillips, 2001). The $\bar{b}_{i} / b$ ratio is 1.15 , indicating local within-plot pedodiversity plays a greater role than between-plot variation.

For rock fragment classes similar results were obtained. For the entire study area, $S=0.74 N^{0.57}$, while mean values for the study plots are $S_{i}=$ $1.17 N_{i}^{0.59}$. The range in $b$ values is $0.37-0.71$, and $\bar{b}_{i} / b=1.04$, indicating that local effects are more important than between-plot variations. The regression results are summarized in Table 5 .

The concentration of rock fragments at the surface and in the A horizon is of particular interest. Because there is no evidence of erosion at the sites and no evidence or history of tillage, any enrichment of the 
surface relative to the subsoil can be attributed only to mass wasting of rock fragments from upper slopes and ridge tops, and/or upward translocation of fragments by tree throw (Phillips and Luckow, 2002). If rock fragments near the surface are due to production by in situ weathering, or are subject to net removal by erosion or mass wasting, then rock content should be at a minimum at the surface, and increase or remain constant with depth.

Of the 58 full-size soil pits, only 7 (12\%) show the lowest rock fragment concentration at the surface, and only 4 (7\%) show increasing or constant concentrations with depth. In 33 cases (57\%) rock fragment concentration was at a maximum at the surface. If subsurface fragments are being brought to the surface by tree throw processes, there should be some enrichment of the surface or A horizon, and rock fragment depletion of subsurface (E or B horizons). In 40 pits $(69 \%)$ rock fragment concentrations are at a minimum in the second mineral horizon (B or E), or surface concentrations are at least $10 \%$ higher than in the second horizon.

\subsection{Tree throws and stumps}

The inventory of tree throws, stumps, and standing dead trees must be a highly contingent snapshot, in that results are likely to vary considerably according to whether, or how recently, events such as storms, fires, pest infestations, logging, or other human impacts have occurred. Notwithstanding this, the inventories do give a general idea of the portion of the soil surface influenced by tree effects. These results, if anything, underestimate tree influences for two reasons. First, they do not include living trees. Second, stumps obviously attributable to logging activity were deliberately excluded, though the pedologic effects of the trees and the stumps are unlikely to differ from those of natural stumps and dead trees.

Results of the inventory are summarized in Table 6. Plots vary greatly in the incidence of tree throw, ranging from none to six throws with a total root wad surface area of more than $20 \mathrm{~m}^{2}$. All plots had tree throws nearby (i.e., visible from within the plot), even if none were found within the plot boundary. Plots averaged about nine standing dead trees and stumps $\geq 5 \mathrm{~cm}$ in diameter (18 total), but basal areas were relatively small (mean of 0.14 and $0.43 \mathrm{~m}^{2}$ for standing dead trees and stumps, respectively). However, due to exclusion of sawn stumps the inventory is biased toward smaller trees.

At 16 pairs of sample sites in various plots one of the soil pits is in a rotted stump flush with the ground

Table 5

Regression results relating soil richness $(S)$ to the number of sample sites $(N)$, of the form $S=c N$

\begin{tabular}{|c|c|c|c|c|c|c|}
\hline \multirow[t]{2}{*}{ Plot } & \multicolumn{3}{|l|}{ Soil types ${ }^{\mathrm{a}}$} & \multicolumn{3}{|c|}{ Rock fragment classes ${ }^{\mathrm{a}}$} \\
\hline & Slope $(b)$ & Intercept $(c)$ & $R^{2}$ & Slope $(b)$ & Intercept $(c)$ & $R^{2}$ \\
\hline $4025 \mathrm{p} 40$ & 0.6206 & 1.0154 & 0.9836 & 0.6278 & 1.2774 & 0.8937 \\
\hline 3100 p1 & 0.5590 & 1.0497 & 0.9868 & 0.5357 & 1.0591 & 0.9865 \\
\hline 3200 p4 & 0.4934 & 0.9835 & 0.9085 & 0.3691 & 0.9770 & 0.9841 \\
\hline 3826 p 28 & 0.5681 & 0.8844 & 0.8104 & 0.5584 & 0.9169 & 0.9332 \\
\hline 3000 p2 & 0.7001 & 1.0679 & 0.9856 & 0.6482 & 1.2141 & 0.9699 \\
\hline 3428 p34 & 0.5438 & 1.2517 & 0.9302 & 0.4939 & 1.3214 & 0.8943 \\
\hline 3514 p12 & 0.6845 & 1.0779 & 0.9791 & 0.5905 & 1.1451 & 0.9736 \\
\hline 3514 p8 & 0.6243 & 1.0930 & 0.9810 & 0.5514 & 1.1930 & 0.9345 \\
\hline 3912 p10 & 0.5062 & 1.1678 & 0.9668 & 0.4841 & 1.1371 & 0.9263 \\
\hline 3627 p34 & 0.7322 & 1.0579 & 0.9699 & 0.6208 & 1.3066 & 0.8855 \\
\hline HW1 & 0.6379 & 1.1310 & 0.9733 & 0.6920 & 1.2145 & 0.9669 \\
\hline $\mathrm{AC} 1$ & 0.6103 & 1.2874 & 0.9218 & 0.5888 & 1.1522 & 0.8902 \\
\hline HW2 & 0.7325 & 0.9804 & 0.9807 & 0.7134 & 1.1360 & 0.9547 \\
\hline Flattop & 0.6494 & 0.9169 & 0.9744 & 0.6041 & 1.1485 & 0.9788 \\
\hline Pine-bluestem & 0.3974 & 1.3595 & 0.8189 & 0.7023 & 1.2813 & 0.9414 \\
\hline Poteau control & 0.7603 & 1.2356 & 0.9681 & 0.6734 & 1.2030 & 0.9730 \\
\hline
\end{tabular}

\footnotetext{
${ }^{\text {a }}$ Soil types refers to the number of different taxa at the series level. Rock fragment classes refers to the number of different classes, as discussed in the text. There are 20 samples per plot.
} 
Table 6

Inventory of tree throws, standing dead trees, and stumps (excluding sawn stumps and tree throws obviously attributable to logging) ${ }^{\mathrm{a}}$

\begin{tabular}{|c|c|c|c|c|c|c|c|}
\hline Plot & $\begin{array}{l}\text { Tree } \\
\text { throws }\end{array}$ & $\begin{array}{l}\text { Tree throw surface } \\
\text { area }\left(\mathrm{m}^{2}\right)\end{array}$ & $\begin{array}{l}\text { Tree throw } \\
\text { volume }\end{array}$ & $\begin{array}{l}\text { Standing dead } \\
\text { trees }\end{array}$ & $\begin{array}{l}\text { Basal area } \\
\left(\mathrm{m}^{2}\right)\end{array}$ & Stumps & $\begin{array}{l}\text { Basal area } \\
\left(\mathrm{m}^{2}\right)\end{array}$ \\
\hline $3200 \mathrm{p} 4$ & 6 & 21.6 & 2.35 & 5 & 0.03 & 8 & 0.47 \\
\hline 3826 p 28 & 2 & 2.3 & 1.1 & 6 & 0.04 & 7 & 0.51 \\
\hline $4025 \mathrm{p} 40$ & 1 & 1.1 & 0.7 & 4 & 0.06 & 4 & 0.09 \\
\hline 3100 p1 & 0 & 0 & 0 & 10 & 0.32 & 10 & 0.37 \\
\hline $3000 \mathrm{p} 2$ & $3^{b}$ & 0 & 0 & 6 & 0.22 & 3 & 0.04 \\
\hline 3428 p34 & 0 & 0 & 0 & 12 & 0.18 & 8 & 0.06 \\
\hline 3514 p12 & 0 & 0 & 0 & 6 & 0.02 & 17 & 0.81 \\
\hline $3514 \mathrm{p} 8$ & 0 & 0 & 0 & 9 & 0.04 & 6 & 0.82 \\
\hline 3912 p10 & 1 & 0.6 & 0.2 & 8 & 0.13 & 15 & 0.61 \\
\hline 3627 p34 & $3^{\mathrm{b}}$ & 0 & 0 & 4 & 0.02 & 17 & 1.51 \\
\hline HW1 & 0 & 0 & 0 & 13 & 0.15 & 8 & 0.36 \\
\hline $\mathrm{AC} 1$ & 3 & 8.9 & 2.5 & 13 & 0.17 & 19 & 0.73 \\
\hline HW2 & 0 & 0 & 0 & 14 & 0.20 & 2 & 0.26 \\
\hline Flattop & 1 & 3.12 & 3.1 & 14 & 0.24 & 11 & 0.19 \\
\hline Pine-bluestem & 0 & 0 & 0 & 3 & 0.08 & 2 & 0.06 \\
\hline Poteau control & 1 & 0.33 & 0.2 & 17 & 0.29 & 7 & 0.04 \\
\hline Mean & 1.3 & 2.4 & 0.6 & 8.9 & 0.14 & 9.0 & 0.43 \\
\hline
\end{tabular}

a Tree throw surface areas and volumes refer to the root wad soil mass.

${ }^{\mathrm{b}}$ The three throws here were apparently older, and there were no remaining soil rootwads to measure.

surface, or a stump hole. During the latter stages of field data collection we developed the hypothesis that trees preferentially occupy sites with fewer rock fragments and/or move fragments away from the tree site. Because soil pits could not be dug under living trees, rotted stump sites allowed an opportunity to compare recent tree sites with adjacent non-tree sites.

Table 7 compares the stump hole samples with their paired sample pits with respect to B horizon rock fragment content and the rock fragment class (see Table 1). Six of the 16 pairs (37.5\%) show clear evidence of lower rock fragments in the stump sample as compared to the adjacent area. Two pairs $(12.5 \%)$ show the opposite trend; in one of these cases there is evidence of surface transport of rock fragments into the stump hole depression. In half the pairs, there was no readily discernible difference in rock fragment content between the stump sample and its companion sample, or the evidence was equivocal.

In five cases (31\%) there was clear field evidence of surface transport of fragments into the stump hole depressions. This may occur by at least two mechanisms. First, rocks initially displaced away from the rooting site by tree growth may fall back into the stump hole depression. Second, rocks moving downslope by mass wasting or displaced by other processes may be deposited in the stump hole. This process would tend to offset the rock fragment impoverishment of tree sites hypothesized in the SRPIT model.

The thickness of the litter layer and O horizon was also compared for the 16 pairs of stump hole sites (Table 8). Stump sites had thicker litter layers in 10 of $16(62.5 \%)$ cases (two were equal), and were much more likely to have extremely thick $(>10 \mathrm{~cm})$ layers. The mean litter thickness was 10.25 and $4.81 \mathrm{~cm}$, respectively, for stump and paired non-stump soils (Table 8). In the six cases (37.5\%) where litter thickness was less than or equal to that of the paired non-stump sample, the stump hole was still occupied by rotten wood, suggesting that continued decomposition would be likely to increase litter thickness in the stump sites.

\section{Discussion}

\subsection{Pedological memory and the SRPIT model}

It is becoming increasingly recognized that minor variations in the initial conditions of soil formation, 
Table 7

Comparison of rock fragment characteristics of rotted stump and stump hole sites with their paired samples

\begin{tabular}{llcccl}
\hline $\begin{array}{l}\text { Plot and } \\
\text { sample pair }\end{array}$ & $\begin{array}{l}\text { B horizon } \\
\text { rock \%: stump }\end{array}$ & $\begin{array}{l}\text { B horizon rock } \\
\% \text { : non-stump }\end{array}$ & $\begin{array}{l}\text { Fragment class: } \\
\text { stump }\end{array}$ & $\begin{array}{l}\text { Fragment class: } \\
\text { non-stump }\end{array}$ & $\begin{array}{l}\text { Evidence of fragment deposition } \\
\text { in stump hole? (notes) }\end{array}$ \\
\hline HW1-1 & $>35$ & 40 & 4 & 5 & Yes \\
HW1-8 & $>70,<35$ & 50 & 12 & 7 & Yes \\
AC1-2 & $<35$ & $>35$ & 2 & 5 & Yes \\
AC1-3 & $<35$ & $<35$ & 3 & 3 & No \\
HW2-4 & $<10$ & 60 & 1 & 5 & No \\
HW2-5 & $>70$ & 40 & 11 & 7 & No \\
HW2-6 & No B & $<35$ & 3 & 1 & No \\
HW2-9 & $<35$ & 10 & 1 & 3 & No \\
PC-1 & $<35$ & $>70$ & 1 & 12 & No \\
PC-3 & $<35$ & $>70$ & 9 & 11 & Yes \\
PC-6 & $>70$ & $<35$ & 12 & 9 & No \\
3627 p34-4 & $>70$ & $>70$ & 3 & 3 & Yes \\
3627 p34-8 & $<35$ & 40 & 3 & 11 & No \\
Flattop-7 & No B & 40 & 9 & 7 & No \\
Pine-Blue 1 & $<35$ & $>70$ & & 5 & \\
Pine-Blue 9 & $>70$ & & 12 & & \\
\hline
\end{tabular}

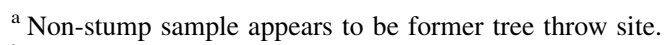

${ }^{\mathrm{b}}$ Both samples may have been subject to recent mass wasting.

or the effects of small and short-lived perturbations (such as biotic effects), can grow unstably over time (Ibañez, 1994; Ibañez et al., 1990; McBratney, 1998; Minasny and McBratney, 1999; Phillips, 1998, 1999, 2000). This produces soil variability that is

Table 8

Comparison of litter thickness $(\mathrm{cm})$ of rotted stump and stump hole sites with their paired samples

\begin{tabular}{lcc}
\hline Sample & Stump & Non-stump \\
\hline HW1-1 & 3 & 3 \\
HW1-8 & 4 & 3 \\
AC1-2 & 13 & 6 \\
AC1-3 & 5 & 5 \\
HW2-4 & 19 & 4 \\
HW2-5 & 4 & 3 \\
HW2-6 & 2 & 6 \\
HW2-9 & 1 & 3 \\
PC-1 & 38 & 6 \\
PC-3 & 31 & 5 \\
PC-6 & 4 & 5 \\
3627 p34-4 & 8 & 10 \\
3627 p34-8 & 14 & 8 \\
Flattop-7 & 11 & 6 \\
Pine-Blue 1 & 2 & 1 \\
Pine-Blue 9 & 5 & 3 \\
Mean & 10.25 & 4.81 \\
\hline
\end{tabular}

disproportionately large compared to measurable, observable variation in factors such as parent material, topography, microclimate, and vegetation that control pedogenesis.

The Ouachita study area exhibits exactly such spatial patterns, with a high degree of soil variability within relatively homogeneous $1271 \mathrm{~m}^{2}$ plots. There are a number of potential mechanisms, particularly when considering magnification by dynamical instability, that might produce such complex spatial patterns. Based on our field observations, we hypothesize that long-lived pedologic impacts of trees are partly responsible for observed variations. Further, we propose that there are self-reinforcing mechanisms whereby tree establishment and pedologic effects of trees are concentrated in favorable rock fragment-poor and nutrient-rich microsites. The SRPIT conceptual model captures these proposed mechanisms, and suggests that over multiple forest generations the preferred tree sites would become increasingly low in rock fragments relative to the soil landscape as a whole, the vertical distribution of rock fragments would be modified, and nutrient content would be increased. Though it is not directly included in the SRPIT model, we might also expect local variations in soil thickness and horizonation to increase over time. 
If the relationships in the SRPIT model are to result in soil divergence (increasing spatial variability) over time, then the relationships between trees, rock fragments in the soil and nutrient status should be dynamically unstable (Ibañez, 1994; Phillips, 2001). Instability implies that minor changes in any component (growth or non-growth of trees, or geomorphic processes modifying rock contents, for example) would persist or grow over time. Analysis of the model by the Routh-Hurwitz criterion shows that it is indeed unstable.

While nutrients are not directly addressed here, the local nutrient enrichment associated with decaying trees is relatively well established. There is also pedologic evidence to support the other mechanisms in the model. Vertical rock fragment distributions suggest that both mass wasting of surface fragments and upward movement by tree uprooting have enriched the soil surface with rock fragments. The relative importance of these processes is difficult to judge, but the ubiquitous presence of surface sandstone fragments on sideslopes regardless of the underlying geology suggests that mass wasting of hard sandstone fragments from the resistant ridgetops is common throughout the area (Phillips and Luckow, 2002). In almost $70 \%$ of the soil pits, however, there is clear enrichment of the rock content of the surface relative to the upper subsoil-exactly the pattern that would be expected if tree throw is preferentially redistributing stones to the surface. This mining of rocks from the subsoil might facilitate the survival and growth of any seedlings that are able to colonize the rock-enriched surface. This is because subsurface fragments may be barriers to root penetration and tend to reduce moisture and nutrient storage.

A comparison of rock fragment characteristics of stump hole and rotted stump sites with paired samples shows some evidence that the stump sites have higher fragment contents. However, the evidence is somewhat equivocal, and complicated by the tendency in some cases for rock fragments to be transported into depressions created by rotting stumps. One possible sequence is as follows: as a seedling becomes established in a rocky surface soil, growth of the tree displaces stones upward and outward, resulting in a stone ring around the base of the tree. Subsequently, decay of the tree (or combustion) creates a depression that the stump ring stones fall into. This would have precisely the opposite effect on vertical rock fragment distributions of tree throw, impoverishing surface stone concentrations and enriching the subsoil. This, in turn, could make seedling establishment more likely but inhibit ultimate tree growth. Stone rings around tree bases were observed in the field, but we have not systematically measured or examined these phenomena. More generally, the relative importance of tree throw, stump rot, and fire could have both pedologic implications and pedologic signatures, implying the possibility of a direct relationship between forest management and soil morphology.

Finally, local within-plot sources of variability in soil types are shown to be more important sources of pedodiversity than between-plot variations. This is consistent with the notion of pedologic impacts of trees on soil morphology, and thus consistent with SRPIT. However, these results are also consistent with variations associated with mechanisms other than the SRPIT model, such as that hypothesized in Fig. 1 and discussed above.

In sum, there appears to be enough evidence to make the SRPIT model worthy of further investigation, though not nearly enough to claim much descriptive or explanatory power yet, in the Ouachitas or elsewhere. We do believe that the biomechanical effects of trees and the role of such effects in local soil variability is clearly worthy of further investigation. Such effects are likely to be important in all forest soils. In rocky soils such as the Ouachita Mountains, however, rock fragments provide a persistent soil property that may facilitate the examination of such effects. The results also suggest that further investigation of the SRPIT model — or other conceptual models based on ecological and pedological memory and nonrandom tree locations-is warranted.

\subsection{Forest management implications}

Results of this study suggest several ways that forest ecology and management may influence soil morphology. This is significant for evaluating forest management policies and practices with respect to impacts on soil, but also for the use of soils and paleosols as indicators of forest ecosystems.

Tree throw is clearly an important biomechanical pedologic process, and this study suggests processes associated with tree growth and stump rot are 
significant as well. Forest management may influence tree throw and stump rot regimes in a number of ways, including:

1. Species mix, particularly pines vs. hardwoods. In the Ouachita study area, pines are more likely to be uprooted than hardwoods, though the opposite may be the case in other settings. This appears to be because ice storms are the predominant tree throw mechanism in the region. Regardless, changes in species composition may change the frequency of tree throw vs. stump rot, and influence soils accordingly.

2. Land-clearing and road-building practices which uproot trees.

3. Changes in canopy coverage and gaps which may modify susceptibility to tree throw caused by ice or wind.

4. Logging, which will eliminate tree throw and promote stump rot.

5. Fire and disease may affect tree throw vs. stump rot directly, due to mortality of trees which are then more susceptible to rot and stem break rather than uprooting. Indirect effects may arise due to influences on species composition, canopy coverage, and other ecological factors.

Tree plantings, particularly in rows or other geometrically systematic patterns, are unaffected by, and are likely to at least partially erase, soil microsite variability. That is, tree sites are determined by silvicultural practices rather than by local variations in rock fragments, nutrients, or other pedological or ecological variables. Thus the SRPIT model is not directly applicable to tree plantations.

\section{Conclusions}

Individual trees may have significant impacts on soil morphology. If these impacts are non-random such that some microsites are repeatedly and preferentially affected by trees, complex local spatial variability of soils would result, via ecological and pedological memory. The self-reinforcing pedologic influences of trees (SRPIT) is proposed to explain patterns of soil variability in the Ouachita Mountains, Arkansas.
The links hypothesized in the SRPIT model are dynamically unstable, which is necessary for the selfreinforcing mechanisms to operate. Soil variability in 16 study plots is dominated by local, within-plot variability, pointing towards the possibility of highly localized biomechanical effects and consistent with the SRPIT model, but also consistent with other localized biotic effects on soil morphology. There is also pedological evidence, albeit equivocal, to support the mechanisms underlying SRPIT. Results suggest that soil morphological effects of individual trees may be a critical source of soil spatial variability in forests, and that such effects may be non-random over time, so that even relatively homogeneous areas may be characterized by tree-rich patches which support repeated generations of trees and tree-poor patches which more rarely host trees.

\section{Acknowledgements}

This project was supported by USDA Forest Service Cooperative grant SRS 01-CA-11330124-516. We thank Ken Luckow, Jan Emerson, J. Swafford, Eric Swafford, Greg Swafford, J. Grant Barber, Raymond McGrath, Freddie Woodral, and Thomas Dozier of the Forest Service for their assistance. Kristin Adams, Linda Martin, Zach Musselman, Alice Turkington, and Taro Futamura of the University of Kentucky assisted in fieldwork.

\section{References}

Barrett, L.R., 1997. Podzolization under forest and stump prairie vegetation in northern Michigan. Geoderma 78, 37-58.

Boettcher, S.E., Kalisz, P.J., 1990. Single-tree influence on soil properties in the mountains of eastern Kentucky. Ecology 71, 1365-1372.

Brewer, R., Merritt, P.G., 1978. Wind throw and tree replacement in a climax beech-maple forest. Oikos 30, 149-152.

Certini, C., Ugolini, F.C., Corti, G., Agnelli, A., 1998. Early stages of podzolization under Corsican pine (Pinus nigra Arn. ssp. laricio). Geoderma 83, 103-125.

Crampton, C.B., 1982. Podzolization of soils under individual tree canopies in southwestern British Columbia, Canada. Geoderma $28,57-61$.

Delcourt, H.R., Delcourt, P.A., 1991. Late-quaternary vegetation history of the Interior Highlands of Missouri, Arkansas, and Oklahoma. In: Henderson, D., Hedrick, L.D. (Eds.), Proceedings of the Conference on Restoration of Old Growth Forests in 
the Interior Highlands of Arkansas and Oklahoma, September 19-20, 1990, Morrilton, AR. USDA Forest Service, Ouachita National Forest and Winrock International Institute for Agricultural Development, Hot Springs, AR, pp. 15-30.

Dobrowolski, J.P., Blackburn, W.H., Pearson, H.A., 1992. Changes to infiltration and interrill erosion from long-term prescribed burning in Louisiana. Water Resour. Bull. 28, 287-298.

Fishwick, P.A., Luker, P.A. (Eds.), 1991. Qualitative Simulation Modeling and Analysis. Advances in Simulation 5. Springer, New York.

Foti, T.L., Glenn, S.M., 1991. The Ouachita Mountain landscape at the time of settlement. In: Henderson, D., Hedrick, L.D. (Eds.), Proceedings of the Conference on Restoration of Old Growth Forests in the Interior Highlands of Arkansas and Oklahoma, September 19-20, 1990, Morrilton, AR. USDA Forest Service, Ouachita National Forest and Winrock International Institute for Agricultural Development, Hot Springs, AR, pp. 49-65.

Graham, R.C., Ervin, J.O., Wood, H.B., 1995. Aggregate stability under oak and pine after four decades of soil development. Soil Sci. Soc. Am. J. 59, 1740-1744.

Haley, G.J., 1979. Soil Survey of Saline County, Arkansas. US Department of Agriculture, Washington.

Harrison, K.G., Post, W.M., Richter, D.D., 1995. Soil carbon turnover in a recovering temperate forest. Glob. Biogeochem. Cycles 9, 449-454.

Ibañez, J.J., 1994. Evolution of fluvial dissection landscapes in Mediterranean environments: quantitative estimates and geomorphic, pedologic, and phytocenotic repercussions. Z. Geomorphol. 38, 105-119.

Ibañez, J.J., De Alba, S., 2000. Pedodiversity and scaling laws: sharing Martin and Rey's opinion on the role of the Shannon index as a measure of diversity. Geoderma 98, 5-9.

Ibañez, J.J., Ballexta, R.J., Alvarez, A.G., 1990. Soil landscapes and drainage basins in Mediterranean mountain areas. Catena 17, 573-583.

Ibañez, J.J., De-Alba, S., Bermudez, F.-F., Garcia-Alvarez, A., 1995. Pedodiversity: concepts and measures. Catena 24, 215-232.

Ibañez, J.J., De-Alba, S., Lobo, A., Zucarello, V., 1998. Pedodiversity and global soil patterns at coarse scales (with Discussion). Geoderma 83, 171-192.

Islam, K.R., Ahmed, M.R., Bhuiyan, M.K., Badruddin, A., 2001. Deforestation effects on vegetative regeneration and soil quality in tropical semi-evergreen degraded and protected forests of Bangladesh. Land Degrad. Dev. 12, 45-56.

Johnson, D.L., 1990. Biomantle evolution and the redistribution of earth materials and artifacts. Soil Sci. 149, 84-102.

Jordan, D.W., Lowe, D.R., Slatt, R.M., Stone, C.G., et al., 1991. Scales of geological heterogeneity of Pennsylvanian Jackfork Group, Ouachita Mountains, Arkansas: applications to field development and exploration for deep-water sandstones. In: Guidebook for the Dallas Geological Society Field Trip \#3. American Association of Petroleum Geologists, 1991 Annual Convention, Dallas, TX, April 4-7, 1991. Arkansas Geological Commission, Little Rock, AR, pp. 1-20 (reprinted, 1993).

Laurent, G.D., Chism, J.D., Rhodes, R.K., Wilson, C.R., Townsend, W.R., 1989. Soil Survey of Garland County, Arkansas. US Department of Agriculture, Washington.
Leth, S., Breuning-Madsen, H., 1992. Changes in soil profile development and nutrient status due to the afforestation of agricultural land. Geograf. Tidsk. 92, 70-74.

Logofet, D.O., 1993. Matrices and Graphs: Stability Problems in Mathematical Ecology. CRC Press, Boca Raton, FL.

Lutz, H.J., Griswold, F.S., 1939. The influence of tree roots on soil morphology. Am. J. Sci. 237, 389-400.

Masters, R.E., Engle, D.M., Robinson, R., 1993. Effects of timber harvest and periodic fire on soil chemical properties in the Ouachita Mountains. South. J. Appl. For. 17, 139-145.

McBratney, A.B., 1998. Some considerations on methods for spatially aggregating and disaggregating soil information. Nutr. Cycl. Agroecosyst. 50, 51-64.

Minasny, B., McBratney, A.B., 1999. A rudimentary mechanistic model for soil production and landscape development. Geoderma 90, 3-21.

Mossa, J., Schumacher, B.A., 1993. Fossil tree casts in south Louisiana soils. J. Sed. Pet. 63, 707-713.

Phillips, J.D., 1993. Spatial-domain chaos in landscapes. Geogr. Anal. 25, 101-117.

Phillips, J.D., 1998. On the relations between complex systems and the factorial model of soil formation (with discussion and response). Geoderma 86, 1-43.

Phillips, J.D., 1999. Earth Surface Systems. Complexity, Order, and Scale. Basil Blackwell, Oxford, UK.

Phillips, J.D., 2000. Signatures of divergence and self-organization in soils and weathering profiles. J. Geol. 108, 91-102.

Phillips, J.D., 2001. Divergent evolution and the spatial structure of soil landscape variability. Catena 43, 101-113.

Phillips, J.D., Luckow, K., 2002. Rock fragments and regolith evolution in the Ouachita Mountains, Arkansas. Abstracts of the 2002 Annual Meeting, North-Central and Southeastern Divisions. Geological Society of America.

Phillips, J.D., Gosweiler, J., Tollinger, M., Mayeux, S., Gordon, R., Altieri, T., Wittmeyer, M., 1994. Edge effects and spatial variability in coastal plain Ultisols. Southeast. Geogr. 34, 125-137.

Phillips, J.D., Perry, D., Carey, K., Garbee, A.R., Stein, D., Morde, M.B., Sheehy, J., 1996. Deterministic uncertainty and complex pedogenesis in some Pleistocene dune soils. Geoderma 73, 147-164.

Puccia, C.J., Levins, R., 1985. Qualitative Modeling of Complex Systems. Harvard University Press, Cambridge, MA.

Retallack, G.J., 1990. Soils of the Past. An Introduction to Paleopedology. Unwin Hyman, London.

Richter, D.D., Markewitz, D., Wells, C.G., Allen, H.L., April, R., Heine, P.R., Urrego, B., 1994. Soil chemical change during three decades in an old-field loblolly pine (Pinus taeda) ecosystem. Ecology 75, 1463-1473.

Schaetzl, R.J., 1990. Effects of treethrow microtopography on the characteristics and genesis of spodosols, Michigan, USA. Catena 17, 111-126.

Schaetzl, R.J., 1994. Changes in O horizon mass, thickness, and carbon content following fire in northern hardwood foests. Vegetation 115, 41-50.

Scatena, F.N., Lugo, A.E., 1995. Geomorphology, disturbance, and the soil and vegetation of two subtropical wet steepland watersheds of Puerto Rico. In: Hupp, C.R., Osterkamp, W., 
Howard, A. (Eds.), Biogeomorphology, Terrestrial and Freshwater Systems. Amsterdam, Elsevier, pp. 199-213.

Schaetzl, R.J., Follmer, L.R., 1990. Longevity of treethrow microtopography: implications for mass wasting. Geomorph. 3, 113-123.

Schaetzl, R.J., Johnson, D.L., Burns, S.F., Small, T.W., 1989. Tree uprooting: review of terminology, process, and environmental implications. Can. J. For. Res. 19, 1-11.

Schaetzl, R.J., Burns, S.F., Small, T.W., Johnson, D.L., 1990. Tree uprooting: review of types and patterns of soil disturbance. Phys. Geogr. 11, 277-291.

Small, T.W., Schaetzl, R.J., Brixie, J.M., 1990. Redistribution and mixing of soil gravels by tree uprooting. Prof. Geogr. 42, $445-457$.

Soil Survey Division Staff, 1993. Soil Survey Manual. US Department of Agriculture, Washington.

Soil Survey Division, 2001. Official Series Descriptions. US Department of Agriculture Database. http://www.statlab.iastate.edu/ soils/osd.

Stanturf, J.A., Marion, D.A., Spetich, M., Luckow, K., Guldin, J.M., Liechty, H.O., Meier, C.E., 2000. Soil quality and productivity responses to watershed restoration in the Ouachita Mountains of Arkansas, USA. In: Hasenhauer, H. (Ed.), Forest Ecosystem Restoration. Proceedings of the International Conference, Vienna, Austria, pp. 391-392.
Stephens, E.P., 1956. The uprooting of trees-a forest process. Soil Sci. Soc. Am. Proc. 20, 113-116.

Stone, C.G., Bush, W.V., 1984. Summary of the geology of the Central and Southern Ouachita Mountains, Arkansas. In: Stone, C.G., Haley, B.R. (Eds.), A Guidebook to the Geology of the Central and Southern Ouachita Mountains, Arkansas. State of Arkansas, Arkansas Geological Commission, Little Rock, AR, pp. 65-75.

Townsend, W.R., Williams, L., 1982. Soil Survey of Perry County, Arkansas. US Department of Agriculture, Washington.

USDA Forest Service, 1999. Ozark-Ouachita Highlands assessment: terrestrial vegetation and wildlife. Report 5 of 5 . General Technical Report SRS-35. USDA Forest Service, Southern Research Station, Asheville, NC, 201 pp.

Van Lear, D.H., Kapeluck, P.R., Carroll, W.D., 2000. Productivity of loblolly pine as affected by decomposing root systems. For. Ecol. Manage. 138, 435-443.

Vasenev, I.I., Targul'yan, V.O., 1995. A model for the development of sod-podzolic soils by windthrow. Eurasian Soil Sci. 27, $1-16$.

Wilson, B.R., Moffatt, A.J., Nortcliff, S., 1997. The nature of three ancient woodland soils in southern England. J. Biogeogr. 24, 633-646.

Zinke, P.J., 1962. The pattern of individual forest trees on soil properties. Ecology 43, 130-133. 